\title{
Editorial
}

\section{MULTIVERSAS CIDADES, TESSITURA DE REDES: ACOMPANHAMENTO TERAPÊUTICO}

Este número vem a público seis anos após a realização do III Congresso Internacional de Acompanhamento Terapêutico, "acontecido" nos dias 9, 10 e 11 de outubro de 2008, na cidade de Porto Alegre. Intitulado Multiversas cidades, andanças caleidoscópicas, tessituras de redes, o evento marcou uma trajetória de encontros em torno do acompanhamento terapêutico e sua tematização, inclusive pelo modo de organização participativo, além da diversidade, originalidade e riqueza dos trabalhos e propostas apresentadas.

O tempo lento em que se preparou esta publicação ${ }^{1}$, reunindo parte desses trabalhos, não reduz o valor nem a atualidade das reflexões que aqui se apresentam. Ao contrário, reafirma a direção então proposta, que toma o acompanhamento terapêutico como dispositivo clínicopolítico transdisciplinar, comum a uma pluralidade de profissões e formações, a operar entre diferentes setores e saberes, ativando redes de "afectos", de apoio e de cuidado.

"A cidade, caleidoscópio de criação", tema da mesa de encerramento do Congresso, fez-se presente, naquele momento, na sensível fala de Miriam Chnaiderman, convidando à rua como espaço de criação, potência de vida e mote à invenção. Ao apresentarmos esta publicação, dobras no tempo fazem reverberar suas palavras, situando o dispositivo clínico - em sua interface com a política - no inusitado que a produção de um documentário conduzido por Miriam, na cidade de Salvador, fazia acontecer ("Fazendo a diferença", 2009).

Em lugar da cidade opressiva e ameaçadora - essa cidade cinzenta de prédios plúmbeos - ver uma cidade com desfiles coloridos de personagens inusitadas. Uma cidade que só se apresenta no momento em que saímos pelas ruas com algo distinto do nosso dia a dia, de nosso cotidiano repetitivo ou rotineiro. Essa cidade que irrompe propõe novas formas de clínica, numa ruptura das formas estabelecidas de interação.

Sair da proteção das quatro paredes de um consultório aconchegante tem sido o dia a dia do meu ofício de documentarista. Nisso, passo a fazer parte do grupo de personagens que transformam a rua em espaço de trabalho, onde caminhadas funcionam como intervenções necessárias nas passagens tão delicadas entre turbilhões internos $e$ externos. A rua torna-se espaço propiciador de uma clínica outra. Refletir sobre a escuta dessa outra cidade, sermos

A edição deste número especial da Revista contou com apoio da CAPES e a parceria do Núcleo de Educação, Avaliação e Produção Pedagógica em Saúde - EducaSaúde, da Universidade Federal do Rio Grande do Sul. transformados pela rua e pelo que ela nos propõe, buscar nomear isso que acontece quando a atenção flutuante acontece nas calçadas e no caminhar, perfazem estrambóticos registros de percursos outros. Percursos traçados por melodias vindas dos cantos, de singularidades nascentes e desdobradas. ${ }^{2}$

A abertura para estar com o outro, entre traçados de vidas que inventam a geografia citadina, nos convoca a uma clínica extramuros, sem muros, feita dos acontecimentos que emergem das andanças pelos espaços e tempos da cidade. A experiência do acompanhamento terapêutico, quando imbuída dessa direção, faz emergir problemáticas que há muito interessam à psicologia social no Brasil, envolvendo as relações entre cidade e subjetividade, entre políticas públicas e redes territoriais de cuidado e entre reforma psiquiátrica e desinstitucionalização da loucura. Em torno desses temas, foram escritos os artigos aqui publicados, convocando à conversa. Ao lado da psicologia social, também a história, a arte, a psicanálise, os direitos humanos, a educação...

Afeitos ao tema de que tratam, um conjunto de autores abre-se para os múltiplos territórios que se intercruzam nas linhas de seus textos. Abandonam certezas próprias e os sistemas fechados, pouco permeáveis à variabilidade dos jogos de forças presentes no território da cidade, para acolher os sentidos inesperados e inconclusos que emergem do uso de seus objetos, seguindo o traçado desviante de suas ruas. Conectados com as ruas, cartografando a cidade no pulsar de um corpo sensível, o acompanhamento terapêutico descobre imanências e convites de composição, esculpe traçados, inventa trajetos, coreografa espontâneos e tece redes.

Leminski nos lembra que "o tempo todo caminha. Se para, acompanha-se de uma só linha: era uma vez, era uma vez, era uma vez". ${ }^{3}$

Convidamos os leitores a acompanhar algumas andanças, caminhos que se seguiram ao era uma vez, não pararam.

\section{Analice de Lima Palombini Gislei Domingas Romanzini Lazzarotto Ricardo Burg Ceccim Editores}

2 Miriam Chnaiderman, na mesa de encerramento do Congresso, em 11 de outubro de 2008 (recorte do texto).

Paulo Leminski, Quarenta Clics em Curitiba, 1976. 